\title{
High-resolution and high-precision correlation of dark and light layers in the Quaternary hemipelagic sediments of the Japan Sea recovered during IODP Expedition 346
}

Ryuji Tada ${ }^{1 *}$ (D) Tomohisa Irino ${ }^{2}$, Ken Ikehara ${ }^{3}$, Akinori Karasuda ${ }^{1}$, Saiko Sugisaki ${ }^{3}$, Chuang Xuan ${ }^{4}$, Takuya Sagawa ${ }^{5}$, Takuya Itaki ${ }^{3}$, Yoshimi Kubota ${ }^{6}$, Song Lu ${ }^{2}$, Arisa Seki ${ }^{1}$, Richard W. Murray ${ }^{7}$, Carlos Alvarez-Zarikian ${ }^{8}$,

William T. Anderson Jr ${ }^{9}$, Maria-Angela Bassetti ${ }^{10}$, Bobbi J. Brace ${ }^{11}$, Steven C. Clemens ${ }^{12}$,

Marcio H. da Costa Gurgel ${ }^{13}$, Gerald R. Dickens ${ }^{14}$, Ann G. Dunlea ${ }^{16}$, Stephen J. Gallagher ${ }^{15}$, Liviu Giosan ${ }^{16}$, Andrew C. G. Henderson ${ }^{17}$, Ann E. Holbourn ${ }^{18}$, Christopher W. Kinsley ${ }^{19}$, Gwang Soo Lee ${ }^{20}$, Kyung Eun Lee ${ }^{21}$, Johanna Lofi ${ }^{22}$, Christina I. C. D. Lopes ${ }^{23}$, Mariem Saavedra-Pellitero ${ }^{24}$, Larry C. Peterson ${ }^{25}$, Raj K. Singh ${ }^{26}$, Samuel Toucanne ${ }^{27}$, Shiming Wan ${ }^{28}$, Hongbo Zheng ${ }^{29}$ and Martin Ziegler ${ }^{30}$

\begin{abstract}
The Quaternary hemipelagic sediments of the Japan Sea are characterized by centimeter- to decimeter-scale alternation of dark and light clay to silty clay, which are bio-siliceous and/or bio-calcareous to a various degree. Each of the dark and light layers are considered as deposited synchronously throughout the deeper (>500 m) part of the sea. However, attempts for correlation and age estimation of individual layers are limited to the upper few tens of meters. In addition, the exact timing of the depositional onset of these dark and light layers and its synchronicity throughout the deeper part of the sea have not been explored previously, although the onset timing was roughly estimated as $\sim 1.5 \mathrm{Ma}$ based on the result of Ocean Drilling Program legs 127/128. Consequently, it is not certain exactly when their deposition started, whether deposition of dark and light layers was synchronous and whether they are correlatable also in the earlier part of their depositional history.

The Quaternary hemipelagic sediments of the Japan Sea were drilled at seven sites during Integrated Ocean Drilling Program Expedition 346 in 2013. Alternation of dark and light layers was recovered at six sites whose water depths are $>\sim 900 \mathrm{~m}$, and continuous composite columns were constructed at each site. Here, we report our effort to correlate individual dark layers and estimate their ages based on a newly constructed age model at Site U1424 using the best available paleomagnetic datum and marker tephras. The age model is further tuned to $L R 04 \delta^{18} \mathrm{O}$ curve using gamma ray attenuation density (GRA) since it reflects diatom contents that are higher during interglacial high-stands. The constructed age model for Site U1424 is projected to other sites using correlation of dark layers to form a high-resolution and high-precision paleo-observatory network that allows to reconstruct changes in material fluxes with high spatio-temporal resolutions.
\end{abstract}

Keywords: Quaternary sediments, Japan Sea, Inter-site correlation, High-resolution age model, IODP, Expedition 346, U1424, U1425, U1426, U1430

\footnotetext{
* Correspondence: ryuji@eps.s.u-tokyo.ac.jp

'Graduate School of Science, The University of Tokyo, Tokyo, Japan

Full list of author information is available at the end of the article
} 


\section{Introduction \\ Background}

The Japan Sea is one of the marginal seas on the western rim of northern Pacific that were formed more or less simultaneously during the Cenozoic. It is the most isolated marginal sea that is connected to neighboring oceans only with shallow ( $<130 \mathrm{~m}$ in sill depth) and narrow (<90 km in width) straits (Fig. 1). Partly because of its semi-isolation, the Japan Sea has its own deep water (called Japan Sea Proper Water), which ventilates the deeper part of the sea with the residence time of 100 years (Gamo et al. 2014), and thus, the sea is occasionally called a miniature ocean (Gamo et al. 2014). The deep water below the water depth of $\sim 2000 \mathrm{~m}$ is highly homogenous with low and nearly constant temperature of $0.04 \sim 0.07{ }^{\circ} \mathrm{C}$, slightly low salinity of $34.07 \%$, low phosphorous of $1.9 \sim 2.2 \mu \mathrm{mol} / \mathrm{kg}$, and high dissolved oxygen of $200 \sim 230 \mu \mathrm{mol} / \mathrm{kg}$ (Talley et al. 2006; Gamo et al. 2014). Consequently, the modern Japan Sea is one of the most oxic ocean basins in the world and relatively poor in nutrients. However, the situation was not necessarily the same in the geological past when sea level and the properties of the inflowing waters were different (e.g., Gallagher et al. 2015). We understand that the marginal sea discussed here is known by different names, including the "Japan Sea" and "East
Sea". In this paper, we use "Japan Sea" given the order of authorship.

\section{Previous studies}

In the summer of 1989, JOIDES Resolution entered the Japan Sea and drilled at six sites during Ocean Drilling Program (ODP) legs 127/128 (Tamaki et al. 1990) to explore its tectonic and paleoceanographic histories. Based on the results of these legs, Tada et al. (1992) reported that Quaternary sediments in the deeper part of the sea are characterized by centimeter- to meter-scale alternations of dark, organic-rich layers and light, organic-poor layers. They further demonstrated that their deposition was synchronous basin-wide and the dark (and light) layers can be correlated in-between sites. Tada et al. (1999) demonstrated that alternation of dark and light layers reflects millennial-scale changes in the contribution of nutrient-rich East China Sea coastal water to the influx through the Tsushima Strait, which probably reflects changes in Yangtze River discharge caused by the changes in East Asian Summer Monsoon intensity in association with the Dansgaard-Oeschger Cycle (DOC) with dark layers deposited during interstadials (see also Tada 2005, 2012). Consequently, the onset timing of the dark and light layer deposition and temporal changes in the amplitude and frequency of their alternation

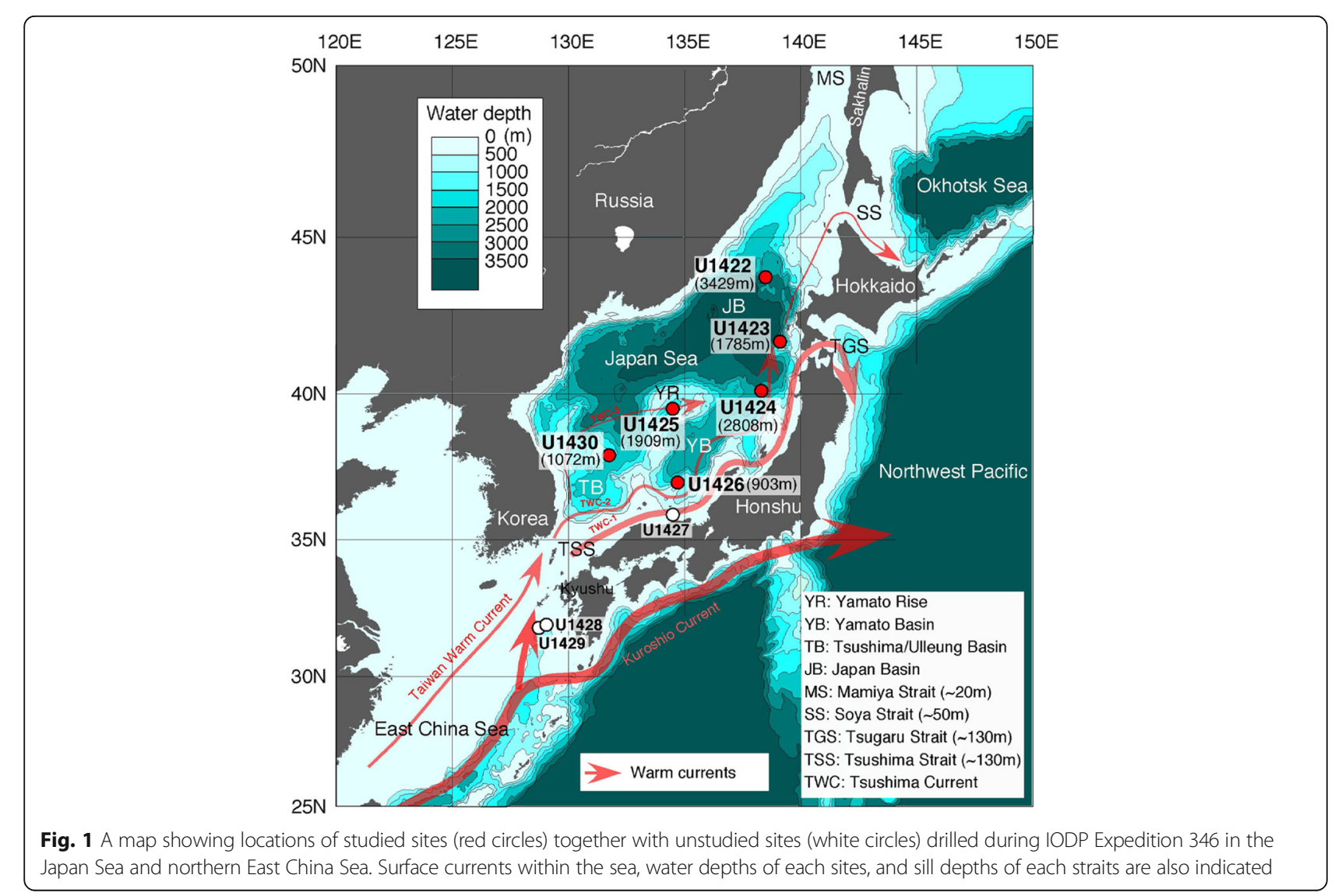


collected wide attention. Tada (2005) estimated the onset timing of the deposition of dark and light layers at approximately 1.5 Ma. However, since drilling was conducted in a single hole, the correlation gaps existed between cores and correlation among the sites was not perfect. Consequently, correlation went back only to 0.7 Ma (Tada et al. 1992). In addition, the age model was of lower resolution and precision since drilling was in a single hole and only limited paleomagnetic and biostratigraphic events were available at that time (e.g., Tada 1994).

\section{Objective of this study}

In order to specify the onset timing of deposition of dark and light layers, to examine the origin and the nature of their alternations, and to explore their temporal changes in frequency and amplitude, Integrated Ocean Drilling Program (IODP) Expedition 346 was conducted in the summer of 2013 and drilled at seven sites in the Japan Sea and two sites in the northern tip of the East China Sea (Fig. 1). To accomplish the objectives described above, high-resolution and high-precision correlation of sedimentary sequences among the sites within the sea is critical, especially for the Quaternary interval. Here, we present a result of group effort to correlate the dark and light layers in the Quaternary interval among six sites located in the deeper (>900 m) parts of the sea where dark and light color contrast is distinct.

\section{Construction and content}

\section{Studied sites}

Seven sites were drilled during the IODP Expedition 346. Sites were selected so that they cover wide ranges of latitude, longitude, and water depths to form a "paleo-observatory network". With respect to the present water depth, Site U1427 is the shallowest site at $\sim 320 \mathrm{~m}$ water depth, Sites U1426 and U1430 are shallower depth sites of around $1000 \mathrm{~m}$, Sites U1425 and U1423 are intermediate depth sites of slightly less than $2000 \mathrm{~m}$, and Sites U1422 and U1424 are the deepest sites in excess of $2800 \mathrm{~m}$ water depth (Fig. 1). Sites U1426 and U1430 are on the bank, Site U1425 is on a terrace within the failed rift in the middle of the Yamato Rise, Sites U1423 and U1427 are on gentle slopes, and Sites U1422 and U1424 are on the basin floor. Sites U1427, U1424, and U1423 are under the influence of the first branch of the Tsushima Warm Current (TWC), Site U1426 is under the influence of the second branch, and Sites U1430 and U1425 are under the influence of the third branch of TWC, respectively. Site U1422 is under the influence of the Liman Cold Current. Sites U1422, U1423, and U1424 were influenced by sea ice at least during the last glacial period (Ikehara 2003). Sites U1427, U1426, and U1425, as well as Sites U1424, U1423, and U1422 can form latitudinal transects; Sites U1427, U1426, U1425, and U1424, as well as Sites U1423 and U1422 can form depth transects; and U1430, U1425, and U1424 can form a longitudinal transect, respectively.

Three to five holes are drilled at each site at least to the depth of $\sim 100 \mathrm{~m}$ so that we can construct a continuous stratigraphic column at each site by core splicing, at least for the Quaternary interval (Tada et al. 2015). Since Sites U1424 and U1426 are drilled approximately at the same locations as ODP Sites 794 and 798, respectively, where previous drilling (legs 127/128) drilled deeper into Miocene, it is possible to use the cores from these sites to complement stratigraphic information on the older part.

\section{Studied methods}

Inter-hole correlations and construction of composite columns It is important to construct perfectly continuous composite columns at all the sites to conduct high-resolution and high-precision correlations of dark and light layers inbetween the sites. We conducted inter-hole correlation of all the recovered cores covering the lithological Unit I (Tada et al. 2015) at each site for this purpose. In addition, interhole correlation of cores enables us to precisely correlate off-splice parts of cores to the composite columns (spliced sections) so that we can use samples taken from off-splice parts of cores in the same way as those taken from the spliced parts and thus can drastically increase the amount of samples utilized for high-resolution studies.

Preliminary inter-hole correlation of cores was conducted onboard by stratigraphic correlators based on RGB (redgreen-blue), GRA (gamma ray attenuation), and NGR (natural gamma ray) profiles taken immediately after core retrieval (Tada et al. 2015). However, there was no time onboard to examine core photographs in detail to crosscheck the validity of inter-hole correlations. For this reason, there were possibilities that stratigraphic gaps and/or repetitions of the sequence caused by small faults mostly formed during drilling were overlooked. Also, drilling disturbance may affect physical properties such as GRA and NGR and even color in some cases, but they are easily overlooked just by examining profiles of physical properties and/or color especially if disturbances are minor. If the core sediments are homogeneous or heavily bioturbated, such small faults or disturbances are difficult to identify. However, in the case of the Quaternary part of the Japan Sea sediments, centimeter- to meter-scale dark and light layers serve as good markers to detect such minor faults and disturbances. We went back to high-resolution core photos of Unit I to identify minor faults, core disturbances, and artificial modifications such as plugging sponges in interstitial water (IW) sampling intervals and modified tie points to avoid such intervals. Details of procedures of inter-hole correlation, revision of tie points, and construction of composite sections are presented in Irino et al. (in press), and we adopt their results (revised composite sections) in this study. 


\section{Inter-site correlations}

Inter-site correlations of dark and light layers are conducted based on visual inspection of composite columns of the six sites. First, we make a continuous composite column at each site using high-resolution core photographs (Irino et al., in press) and pick up relatively thick and distinct dark layers as marker layers. We set the bottom of marker dark layers as correlation tie points since many of the dark layers are laminated especially at their bottoms; thus, the effect of bioturbation is minimal (Watanabe et al. 2007). We use a composite column of Site U1424 as a reference column since its preliminary age model (Tada et al. 2015) suggests that the linear sedimentation rate (LSR) is more or less constant throughout the Quaternary and no significant sedimentation break exists. In addition, magnetostratigraphic events are best identified (Xuan et al., 2018, personal communication) and the largest number of tephra layers is found at this site. Next, we visually correlate marker dark layers at Site U1424 with those at other sites from the top of the column downward. We use marker tephra layers (Sagawa et al., in press) and magnetostratigraphic events (Xuan et al., 2018, personal communication) as guides to correlate marker dark layers among the sites. After inter-site correlation is completed, photographs of composite columnar sections of each sites are adjusted in their lengths at the core top and the Brunhes/Matsuyama boundary so that we can visually check the appropriateness of inter-site correlation of marker dark layers (Additional file 1: Figure S1).

\section{Construction of the age model}

The master age model of Unit I is constructed for Site U1424 where sedimentation seems continuous with relatively constant LSR, magnetostratigraphic events are best defined, and the largest number of tephra are identified among the six deeper sites drilled in the Japan Sea during Exp. 346. We use the revised magnetostratigraphy of Xuan et al. 2018 (personal communication) and tephrochronology of Sagawa et al. (in press) and Satoguchi and Nagahashi (2012) to construct an age model, which we call a tephra-p-mag-based age model (Fig. 2). The datum used to construct the age model is listed in Table 1.

A tephra-p-mag-tuned age model is further tuned to LR04 age model (Lisiecki and Raymo 2005) by visually correlating GRA and NGR composite profiles of U1424 to LR04 $\delta^{18} \mathrm{O}$ stack of benthic foraminifers. It is well known that GRA decreases with the increase in diatom contents because diatom frustules have high internal porosity (Tada and Iijima 1983). NGR also decreases with the increase in diatom contents because diatoms dilute detrital material. In case of the Quaternary sediments of the Japan Sea, diatom abundance strongly links to glacio-eustatic sea level because surface productivity of the sea is controlled by nutrient influx through the Tsushima Strait, which in turn

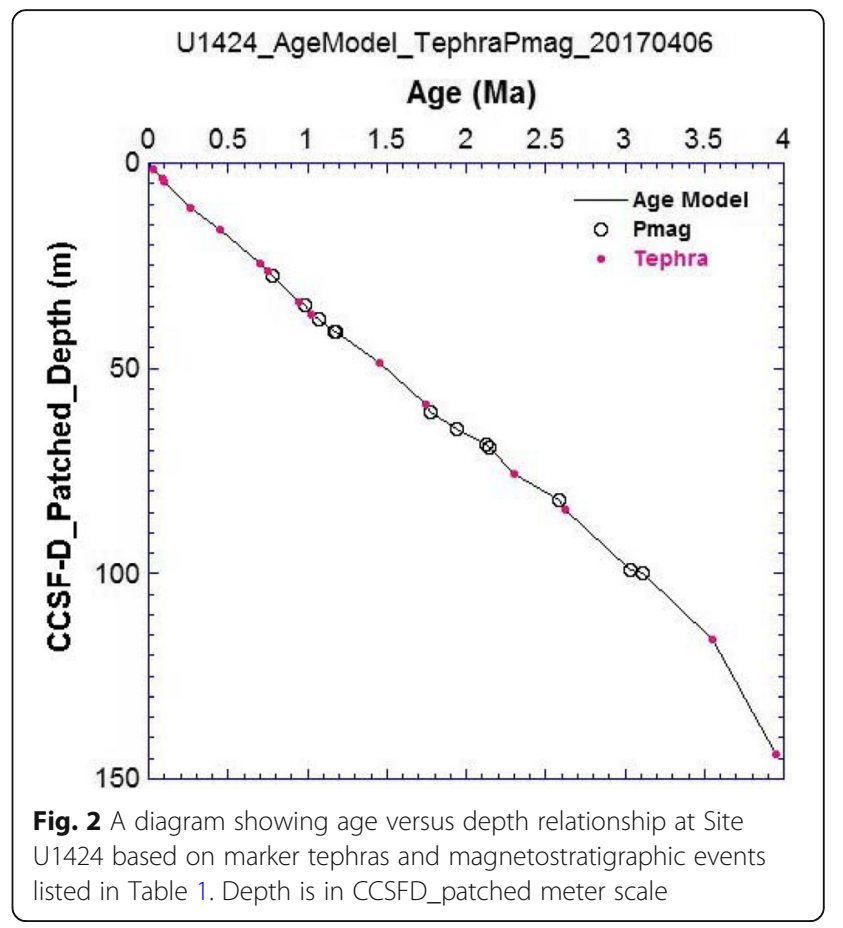

has been modulated by glacio-eustatic sea level changes (Tada et al. 1992, 1999; Tada 2012). Because the Tsushima Strait is only $130 \mathrm{~m}$ deep and its width and depth increase with the rise in sea level, the influx of the TWC is expected to increase drastically with the rise in sea level. Thus, diatom abundance can be used as a sea level proxy.

Tuning of U1424 age to LR04 age is conducted for the last $\sim 3$ m.y. based on visual correlation of the GRA and NGR composite profiles with LR04 $\delta^{18} \mathrm{O}$ stack profile. We put priority on GRA over NGR for correlation because GRA data has higher resolution than NGR. We then cross-check the correlation by comparing LR04 stack profile with NGR profile. For most of glacialinterglacial cycles, GRA and NGR profiles show patterns similar to each other without phase shift and thus confirm the correlation based on GRA. For several intervals where the GRA profile does not show a clear pattern similar to LR04 $\delta^{18} \mathrm{O}$ stack profile, NGR profile is used for correlation. The correlation of GRA and NGR with LR04 $\delta^{18} \mathrm{O}$ stack is shown in Additional file 2: Figure S2 and CCSF-D_patched depth and age for each correlation point are listed in Table 2 where CCSF-D_patched depth is the depth scale for the revised composite section. A resulted LR04-tuned age model is shown in Fig. 3.

\section{Results and discussion}

\section{Age estimation of marker dark layers}

In this study, we first constructed perfectly continuous composite columns for the entire Quaternary sequences at the six deeper sites studied, and using these composite columns, we correlated distinct dark layers among the sites 
Table 1 A list of tephras and magnetostratigraphic events, their composite depths (CCSFD_patched), ages, and references used to construct a tephra and p-mag based age model shown in Fig. 2

\begin{tabular}{|c|c|c|c|c|c|}
\hline Control No. & Event name & Other name & Age (Ma) & CCSF-D (m) & CCSF-D_Patched (m) \\
\hline 0 & Core top & & 0 & 0.000 & 0.000 \\
\hline T01 & AT & & 0.03 & 1.659 & 1.350 \\
\hline T02 & BT22 & Aso-4 & 0.09 & 3.960 & 3.860 \\
\hline T03 & JS72 & Toya & 0.10 & 4.750 & 4.650 \\
\hline TK01 & Aso-1 & & 0.26 & 10.852 & 11.002 \\
\hline TK02 & B-Og & & 0.45 & 16.675 & 16.215 \\
\hline T04 & Ka1 & & 0.7 & 24.458 & 24.358 \\
\hline T05 & Imakuma1 & $\mathrm{Hkd}-\mathrm{Ku}$ & 0.75 & 26.527 & 26.427 \\
\hline PM01 & Bot C1n & $\mathrm{B} / \mathrm{M}$ & 0.78 & 27.542 & 27.442 \\
\hline T06 & Yamada1 & & 0.95 & 33.871 & 33.751 \\
\hline PM02 & Top C1r.1n & Top Jarallillo & 0.99 & 34.941 & 34.821 \\
\hline T07 & Pink & SS-Pnk & 1.02 & 36.795 & 37.121 \\
\hline PM03 & Bot C1r.1n & Bot Jarallillo & 1.07 & 37.741 & 38.101 \\
\hline PM04 & Top C1r.2n & Top Cobb Mountain & 1.17 & 40.635 & 40.995 \\
\hline PM05 & Bot C1r.2n & Bot Cobb Mountain & 1.19 & 40.845 & 41.205 \\
\hline T08 & $\mathrm{Kd} 18 ?$ & Ak-Kd18 & 1.45 & 47.586 & 48.436 \\
\hline T09 & Fukuda & Eb-Fkd & 1.75 & 57.812 & 58.662 \\
\hline PM06 & Top C2n & Top Olduvai & 1.78 & 59.692 & 60.542 \\
\hline PM07 & Bot C2n & Bot Olduvai & 1.95 & 63.902 & 64.752 \\
\hline PM08 & Top C2r.1n & Top Reunion & 2.13 & 67.913 & 68.763 \\
\hline PM09 & Bot C2r.1n & Bot Reunion & 2.15 & 68.406 & 69.256 \\
\hline T10 & Mushono & Msn-Jwg4 & 2.3 & 74.727 & 75.577 \\
\hline PM10 & Top C2An.1n & $M / G$ & 2.58 & 81.396 & 82.246 \\
\hline T11 & Asashiro & Ass-Tmd2 & 2.62 & 83.231 & 84.451 \\
\hline PM11 & Top C2An.1r & Top Kaena & 3.03 & 97.682 & 98.992 \\
\hline PM12 & Bot C2An.1r & Bot Kaena & 3.12 & 98.537 & 99.847 \\
\hline $\mathrm{T} 12$ & Souri & Sr-lty & 3.55 & 114.662 & 115.972 \\
\hline T16 & Ohta & Znp-Ohta & 3.95 & 142.667 & 143.977 \\
\hline
\end{tabular}

for the interval covering the last $1.5 \mathrm{My}$ corresponding to the lithological Subunit IA (Additional file 1: Figure S1). Then, we constructed a high-resolution and high-precision age model at Site U1424 based on correlation of GRA and NGR with LR04 $\delta^{18} \mathrm{O}$ stack (Additional file 2: Figure S2). By using this age model, it is possible to estimate the ages of individual marker dark layers and thus project their ages to other sites.

\section{Coding of dark layers}

As is described above, dark layers are useful markers to make a high-resolution correlation between sites and assign precise ages to the sedimentary sequences in the deeper part of the Japan Sea. Consequently, it is useful to give them code numbers so that we can easily identify dark layers of our interest and estimate their ages. As to the last glacial period, thinly laminated (TL) layer numbering was conducted in the way so that TL numbers agree with interstadial numbers of DOC (Tada et al. 1999; Dansgaard et al. 1993). No numbering has been made on dark layers deposited before Marine isotope stage (MIS) 6 except by Tada et al. (1992) who made tentative naming of distinct dark layers at ODP Sites 794, 795, and 797. However, their naming was not systematic and went back to only ca. $0.7 \mathrm{Ma}$.

In this study, we conduct numbering of the marker dark layers in Subunit IA covering the last 1.45 Ma. We first identify relatively thick and distinct dark layers as marker layers for the purpose of inter-site correlation as is described above. Then, using these marker dark layers and tephra layers as guides, we further identify thinner but distinct dark layers that can be correlated among the deeper six sites and can be used as second order marker layers. The results are listed in Additional file 3: Table S1. 
Table 2 A list of correlation point numbers, their depths (CCSFD_patched) on U1424 composite column, and their corresponding ages on LR04 $\delta^{18} \mathrm{O}$ stack profile. Correlation points are also shown in Additional file 2: Figure S2

\begin{tabular}{|c|c|c|c|c|c|c|c|c|c|c|c|c|}
\hline Exp & Site & Hole & Core & Type & Sect & A/W & Offset $(\mathrm{cm})$ & CSF-A (m) & CCSF-A (m) & CCSF-D_Patched (m) & Age Control No. & LR04-tuned Age (Ma) \\
\hline 346 & U1424 & A & 1 & $\mathrm{H}$ & 1 & A & 97.0 & 0.97 & 0.97 & 0.97 & 1 & 0.018 \\
\hline 346 & U1424 & A & 1 & $\mathrm{H}$ & 3 & A & 20.0 & 3.20 & 3.20 & 3.10 & 2 & 0.069 \\
\hline 346 & U1424 & B & 2 & $\mathrm{H}$ & 1 & A & 120.0 & 3.90 & 6.05 & 5.95 & 3 & 0.135 \\
\hline 346 & U1424 & B & 2 & $\mathrm{H}$ & 2 & A & 6.0 & 4.26 & 6.41 & 6.31 & 4 & 0.156 \\
\hline 346 & U1424 & B & 2 & $\mathrm{H}$ & 3 & A & 144.0 & 7.14 & 9.29 & 9.19 & 5 & 0.223 \\
\hline 346 & U1424 & B & 2 & $\mathrm{H}$ & 4 & A & 125.0 & 8.45 & 10.60 & 10.50 & 6 & 0.246 \\
\hline 346 & U1424 & B & 2 & $\mathrm{H}$ & 5 & A & 78.0 & 9.48 & 11.63 & 11.53 & 7 & 0.278 \\
\hline 346 & U1424 & B & 2 & $\mathrm{H}$ & 5 & A & 135.5 & 10.06 & 12.21 & 12.11 & 8 & 0.294 \\
\hline 346 & U1424 & A & 2 & $\mathrm{H}$ & 5 & A & 29.0 & 13.09 & 13.86 & 13.76 & 9 & 0.341 \\
\hline 346 & U1424 & B & 3 & $\mathrm{H}$ & 2 & A & 28.0 & 13.98 & 16.44 & 16.34 & 10 & 0.431 \\
\hline 346 & U1424 & B & 3 & $\mathrm{H}$ & 3 & A & 130.5 & 16.51 & 18.97 & 18.87 & 11 & 0.513 \\
\hline 346 & U1424 & B & 3 & $\mathrm{H}$ & 4 & A & 52.5 & 17.23 & 19.69 & 19.59 & 12 & 0.536 \\
\hline 346 & U1424 & A & 3 & $\mathrm{H}$ & 2 & A & 127.5 & 19.08 & 20.97 & 20.87 & 13 & 0.583 \\
\hline 346 & U1424 & A & 3 & $\mathrm{H}$ & 4 & A & 15.0 & 20.95 & 22.85 & 22.75 & 14 & 0.630 \\
\hline 346 & U1424 & B & 4 & $\mathrm{H}$ & 1 & A & 87.5 & 22.58 & 25.79 & 25.69 & 15 & 0.718 \\
\hline 346 & U1424 & A & 3 & $\mathrm{H}$ & 6 & A & 74.0 & 24.54 & 26.44 & 26.34 & 16 & 0.746 \\
\hline 346 & U1424 & B & 4 & $\mathrm{H}$ & 2 & A & 147.0 & 24.67 & 27.89 & 27.79 & 17 & 0.794 \\
\hline 346 & U1424 & B & 4 & $\mathrm{H}$ & 4 & A & 102.5 & 27.23 & 30.44 & 30.34 & 18 & 0.872 \\
\hline 346 & U1424 & A & 4 & $\mathrm{H}$ & 2 & A & 104.0 & 28.34 & 31.64 & 31.54 & 19 & 0.922 \\
\hline 346 & U1424 & A & 4 & $\mathrm{H}$ & 4 & A & 30.0 & 30.60 & 33.90 & 33.78 & 20 & 0.964 \\
\hline 346 & U1424 & A & 4 & $\mathrm{H}$ & 4 & A & 122.5 & 31.53 & 34.83 & 34.71 & 21 & 0.986 \\
\hline 346 & U1424 & C & 4 & $\mathrm{H}$ & 5 & A & 119.5 & 33.10 & 36.42 & 36.33 & 22 & 1.038 \\
\hline 346 & U1424 & B & 5 & $\mathrm{H}$ & 3 & A & 107.0 & 34.73 & 38.13 & 38.49 & 23 & 1.098 \\
\hline 346 & U1424 & B & 5 & $\mathrm{H}$ & 4 & A & 72.5 & 35.89 & 39.29 & 39.65 & 24 & 1.122 \\
\hline 346 & U1424 & B & 5 & $\mathrm{H}$ & 5 & A & 79.0 & 37.45 & 40.85 & 41.21 & 25 & 1.198 \\
\hline 346 & U1424 & A & 5 & $\mathrm{H}$ & 2 & A & 134.5 & 38.15 & 42.14 & 42.50 & 26 & 1.248 \\
\hline 346 & U1424 & $C$ & 5 & $\mathrm{H}$ & 3 & A & 85.0 & 39.25 & 43.30 & 44.06 & 27 & 1.290 \\
\hline 346 & U1424 & A & 5 & $\mathrm{H}$ & 4 & A & 102.5 & 40.83 & 44.82 & 45.59 & 28 & 1.336 \\
\hline 346 & U1424 & A & 5 & $\mathrm{H}$ & 5 & A & 114.0 & 42.44 & 46.44 & 47.25 & 29 & 1.412 \\
\hline 346 & U1424 & B & 6 & $\mathrm{H}$ & 2 & A & 135.5 & 43.43 & 47.79 & 48.64 & 30 & 1.456 \\
\hline 346 & U1424 & B & 6 & $\mathrm{H}$ & 4 & A & 17.5 & 45.25 & 49.61 & 50.46 & 31 & 1.496 \\
\hline 346 & U1424 & B & 6 & $\mathrm{H}$ & 5 & A & 112.0 & 47.69 & 52.06 & 52.91 & 32 & 1.535 \\
\hline 346 & U1424 & A & 6 & $\mathrm{H}$ & 3 & A & 58.0 & 48.38 & 52.95 & 53.80 & 33 & 1.575 \\
\hline 346 & U1424 & A & 6 & $\mathrm{H}$ & 4 & A & 62.5 & 49.93 & 54.49 & 55.34 & 34 & 1.613 \\
\hline 346 & U1424 & A & 6 & $H$ & 5 & A & 37.0 & 51.17 & 55.74 & 56.59 & 35 & 1.655 \\
\hline 346 & U1424 & A & 6 & $\mathrm{H}$ & 5 & A & 129.5 & 52.10 & 56.66 & 57.51 & 36 & 1.700 \\
\hline 346 & U1424 & B & 7 & $\mathrm{H}$ & 2 & A & 137.0 & 53.07 & 58.30 & 59.15 & 37 & 1.748 \\
\hline 346 & U1424 & B & 7 & $\mathrm{H}$ & 4 & A & 37.5 & 55.08 & 60.31 & 61.16 & 38 & 1.795 \\
\hline 346 & U1424 & B & 7 & $\mathrm{H}$ & 5 & A & 21.5 & 56.42 & 61.65 & 62.50 & 39 & 1.863 \\
\hline 346 & U1424 & B & 7 & $\mathrm{H}$ & 6 & A & 36.5 & 58.07 & 63.30 & 64.15 & 40 & 1.900 \\
\hline 346 & U1424 & A & 7 & $\mathrm{H}$ & 4 & A & 55.0 & 59.35 & 64.48 & 65.33 & 41 & 1.948 \\
\hline 346 & U1424 & A & 7 & $\mathrm{H}$ & 5 & A & 7.0 & 60.37 & 65.50 & 66.35 & 42 & 2.000 \\
\hline 346 & U1424 & A & 7 & $\mathrm{H}$ & 5 & A & 142.0 & 61.72 & 66.85 & 67.70 & 43 & 2.065 \\
\hline
\end{tabular}


Table 2 A list of correlation point numbers, their depths (CCSFD_patched) on U1424 composite column, and their corresponding ages on LR04 $\delta^{18} \mathrm{O}$ stack profile. Correlation points are also shown in Additional file 2: Figure S2 (Continued)

\begin{tabular}{|c|c|c|c|c|c|c|c|c|c|c|c|c|}
\hline Exp & Site & Hole & Core & Type & Sect & A/W & Offset $(\mathrm{cm})$ & CSF-A (m) & CCSF-A (m) & CCSF-D_Patched (m) & Age Control No. & LR04-tuned Age (Ma) \\
\hline 346 & U1424 & $B$ & 8 & $\mathrm{H}$ & 3 & A & 11.5 & 62.82 & 68.88 & 69.73 & 44 & 2.155 \\
\hline 346 & U1424 & B & 8 & $\mathrm{H}$ & 3 & A & 149.0 & 64.19 & 70.25 & 71.10 & 45 & 2.200 \\
\hline 346 & U1424 & B & 8 & $\mathrm{H}$ & 4 & A & 117.5 & 65.38 & 71.44 & 72.29 & 46 & 2.240 \\
\hline 346 & U1424 & B & 8 & $\mathrm{H}$ & 5 & A & 49.0 & 66.19 & 72.25 & 73.10 & 47 & 2.275 \\
\hline 346 & U1424 & A & 8 & $\mathrm{H}$ & 4 & A & 52.5 & 68.83 & 73.44 & 74.29 & 48 & 2.313 \\
\hline 346 & U1424 & A & 8 & $\mathrm{H}$ & 5 & A & 52.0 & 70.32 & 74.94 & 75.79 & 49 & 2.358 \\
\hline 346 & U1424 & B & 9 & $\mathrm{H}$ & 1 & A & 130.0 & 70.50 & 77.14 & 77.99 & 50 & 2.433 \\
\hline 346 & U1424 & B & 9 & $\mathrm{H}$ & 2 & A & 110.5 & 71.77 & 78.41 & 79.26 & 51 & 2.488 \\
\hline 346 & U1424 & B & 9 & $\mathrm{H}$ & 3 & A & 74.5 & 72.91 & 79.55 & 80.40 & 52 & 2.518 \\
\hline 346 & U1424 & B & 9 & $\mathrm{H}$ & 4 & A & 60.0 & 74.26 & 80.90 & 81.75 & 53 & 2.565 \\
\hline 346 & U1424 & A & 9 & $\mathrm{H}$ & 3 & A & 50.5 & 76.81 & 82.15 & 83.09 & 54 & 2.600 \\
\hline 346 & U1424 & B & 9 & $\mathrm{H}$ & 5 & A & 139.5 & 76.56 & 83.20 & 84.42 & 55 & 2.645 \\
\hline 346 & U1424 & B & 9 & $\mathrm{H}$ & 6 & A & 124.5 & 77.91 & 84.55 & 85.86 & 56 & 2.688 \\
\hline 346 & U1424 & A & 9 & $\mathrm{H}$ & 5 & A & 66.5 & 79.97 & 85.31 & 86.62 & 57 & 2.715 \\
\hline 346 & U1424 & B & 10 & $\mathrm{H}$ & 3 & A & 122.5 & 82.93 & 89.75 & 91.06 & 58 & 2.805 \\
\hline 346 & U1424 & B & 10 & $\mathrm{H}$ & 5 & A & 89.0 & 85.59 & 92.41 & 93.72 & 59 & 2.878 \\
\hline 346 & U1424 & A & 10 & $\mathrm{H}$ & 4 & A & 102.5 & 88.33 & 94.18 & 95.49 & 60 & 2.920 \\
\hline 346 & U1424 & A & 10 & $\mathrm{H}$ & 5 & A & 117.0 & 89.97 & 95.83 & 97.14 & 61 & 2.975 \\
\hline
\end{tabular}

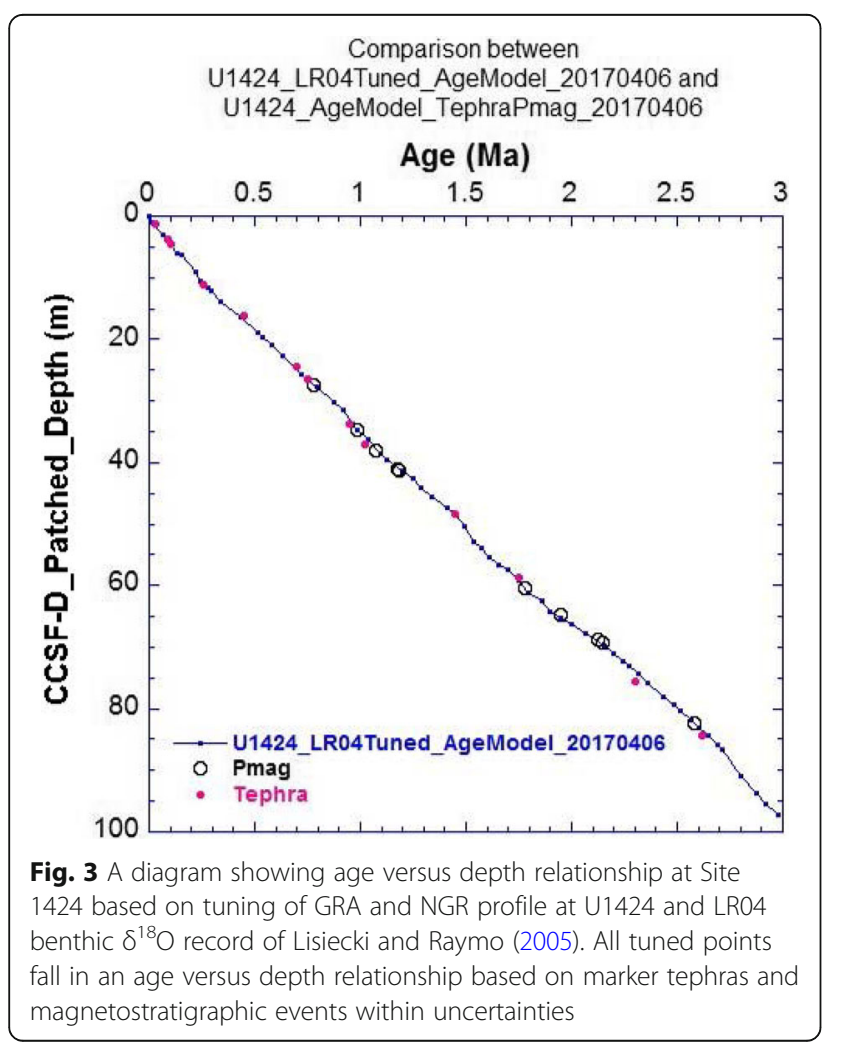

The relatively thick and distinct dark layers occur every several meters and they tend to be associated with quasicyclic changes in amplitude and frequency of sediment lightness $\left(L^{*}\right)$ in Subunit IA, which seems to be associated with glacial-interglacial sea level changes as will be discussed later. In brief, thicker dark layers tend to occur during glacial maxima especially when sea level was lowered by more than $100 \mathrm{~m}$ and euxinic deep water emerged due to development of low-salinity surface water (Tada et al. 1999; Kido et al. 2007; also Seki 2017). Thick dark layers accumulated under euxinic deep water were found during MIS 2, 6, 10, 12, 16, 20, and 22 (Seki 2017). Such dark layers are overlain by thick light layers which were deposited during interglacial maxima. These characteristics are less clear before MIS 22 $(\sim 0.9 \mathrm{Ma})$ when thick diatomaceous dark layers frequently deposited during interglacial maxima.

We define a cycle of such several meter-scale change in amplitude and frequency of lightness as starting from the top of a relatively thick and distinct dark layer downward to the base of the relatively thick light layer so that one cycle basically corresponds to one glacial-interglacial cycle. From the core top downward, cycle number starts from 0 and increases downward. Because we tune changes in sea level proxies such as GRA and NGR to LR04 $\delta^{18} \mathrm{O}$ stack so as to construct high-resolution age model for Unit I as described above, and because one cycle basically represents one glacial-interglacial cycle, there is a relation between a cycle number and MIS number. Namely, 


$$
X=Y / 2-1
$$

where $X$ is a cycle number and $Y$ is an MIS number when the thick dark layer at the top of cycle $X$ deposited. Exceptions are cycle 0 that corresponds to the Holocene when no thick dark layer exists at the top, cycle 1 whose top thick dark layer corresponds to MIS 2 and thus $X=Y / 2$, cycle 20 whose thick and dark layer deposited during MIS 45 (interglacial period) and thus $X=Y / 2-2.5$, and cycle 21 whose thick dark layer deposited at MIS 46 and thus $X$ $=Y / 2-2$. A relatively thick and distinct dark layer at a top of cycle $X$ is named Dark Layer (DL)- $X-1$ (Additional file 1: Figure S1; Additional file 3: Table S1). Every cycle contains several thinner but still distinct dark layers that are possible to correlate in-between sites. We put numbers $2,3, \ldots$ on them in descending order and described as suffixes to the cycle number. Namely, $Z$ th dark layer in cycle $X$ is $\mathrm{DL}-X-Z$. In Additional file 3: Table S1, we list ages at the base of each dark layer based on tephra-p-mag-tuned and LR04-tuned age models for the last $\sim 3 \mathrm{My}$. We also list depths and ages at the top of marker dark layer that define the top of each cycle, although it should be noted that their depths and ages may be less well defined and could be slightly diachronous due to the result of bioturbation.

\section{Temporal and spatial changes in linear sedimentation rates (LSRs) in the Japan Sea during the last $1.45 \mathrm{My}$} As is described in the previous section, we estimated the age at the base of each marker dark layer at Site 1424 and projected its age to other sites based on inter-site correlation described above (Table 2). By using these data, it is possible to calculate linear sedimentation rates (LSRs) at all the six sites with high time resolution (Additional file 4: Table S2). Additional file 5: Figure S3 shows temporal changes in LSRs at all sites. LSRs are more or less constant at 4 and $\sim 3 \mathrm{~cm} / \mathrm{ky}$ at Sites U1422 and U1424 (deeper sites); gradually increasing from $\sim 3$ to $\sim 10 \mathrm{~cm} / \mathrm{ky}$, from $\sim 2$ to $\sim 7 \mathrm{~cm} / \mathrm{ky}$, and from $\sim 2$ to $\sim 8 \mathrm{~cm} / \mathrm{ky}$ at Sites U1423, U1425, and U1430 (intermediate depths sites); and relatively high and more or less constant at $\sim 10 \mathrm{~cm} / \mathrm{ky}$ at Site U1426 (shallow site), respectively. Exceptions are between $\sim 850$ and $\sim 1200$ ka when LSRs are slightly higher and variable and after $\sim 250 \mathrm{ka}$ when LSRs increase upward. At Site U1430, extremely low LSR is observed at $\sim 800 \mathrm{ka}$.

In general, LSR tends to be lower at deeper sites, which probably reflects dissolution of carbonate (and biogenic silica to some extent). The upward increase in LSRs after $\sim 250 \mathrm{ka}$ is probably because near-surface sediments are less compacted. The gradually increasing trend of LSR at intermediate depth sites can be partly due to lesser degree of compaction, but the increasing trends started from deeper parts. The upward increasing trend of LSRs could be explained by the upward increase in biogenic carbonate content due to deepening of calcium carbonate compensation depth (CCD) that crossed the intermediate depths of 1000 to $2000 \mathrm{~m}$ at $\sim 1.0 \mathrm{Ma}$. Variable LSRs between $\sim 850$ and $\sim 1200$ ka could be related to large amplitude changes of CCD during transition from shallower CCD before 1200 ka to deeper CCD after $850 \mathrm{ka}$. Mass accumulation rate (MAR) calculation of carbonate at these sites based on high-resolution XRF core scanner and gamma ray attenuation (GRA) porosity data combined with LSR data will be necessary to test this possibility.

\section{Establishment of paleo-observatory network}

Reconstruction of material cycling such as carbon, sulfur, and phosphorous within the earth surface is critical to understand dynamics and controlling mechanisms of climatic changes in the past and preparing for the future. Especially, changes in centennial to millennial time scales are of prime importance since they are beyond the coverage of observational records, but still, climatic changes of such time scales are relevant to the society. Spatial coverage is also important since spatial changes in mass flux often give clues to understand the processes within the system of interest and their controlling factors. However, it is generally difficult to correlate geological records from different localities with high time precision and resolution. In this respect, Quaternary hemipelagic sediments of the Japan Sea provide a rare opportunity to study spatiotemporal changes of mass flux with high time precision and resolution. Namely, marker dark layers and tephra layers can be correlated with the time precision of less than 100 years, and approximately 250 marker layers are defined during the last $1.45 \mathrm{Ma}$, providing $\sim 6 \mathrm{ky}$ resolution in average. These time precision and resolution are an order of magnitude higher than those for other correlation methods such as biostratigraphy, paleomagnetism, and radiometric dating. In addition, dry bulk density of the sediments can be estimated from GRA data measured onboard. Thus, it is possible to reconstruct MARs with an average time resolution of $\sim 6 \mathrm{ky}$ at the six deeper IODP sites that cover the area more than a half of the Japan Sea. Moreover, we can calculate MAR of individual chemical element and/or mineral by combining high-resolution MAR data with high-resolution chemical and/or mineralogical analyses data.

In this study, we propose to utilize the six IODP sites in the Japan Sea as paleo-observatory network since highprecision age data and high-resolution LSRs and GRA data are available; the sites cover wide latitude, longitude, and water depth ranges; proxy data at each site can be 
correlated with precision of less than 100 years; and good amount of samples are still available from IODP.

\section{Conclusions}

The Quaternary hemipelagic sediments in the Japan Sea (Subunit IA) are characterized by centimeter- to decimeter-scale alternation of dark and light layers. Over 250 dark layers are present and 64 distinct dark layers are chosen that are traceable throughout the deeper (>500 $\mathrm{m}$ water depth) part of the basin and correlated in-between the six sites (U1422, 1423, 1424, 1425, 1426, and 1430) drilled by IODP Expedition 346. An age model covering the last $3 \mathrm{My}$ is constructed at Site U1424 based on tephra-chronology and magnetostratigraphy, which is further tuned to LR04 age using GRA profile, a proxy for sea level change in the Quaternary Japan Sea, correlated to LR0 $4 \delta^{18} \mathrm{O}$ stack profile. We estimate ages of marker dark layers at Site U1424, which are projected to other sites based on inter-site correlation of marker dark layers. In this way, we establish paleo-observatory network covering the last $1.45 \mathrm{My}$ in the Southeastern half of the Japan Sea. This network will greatly enhance our understanding on material cycling in the Japan Sea.

\section{Additional files}

Additional file 1: Figure S1. Figures showing inter-site correlation of marker dark layers in Subunit IA among six deeper sites in the Japan Sea drilled during Expedition 346. a From 0 to $0.8 \mathrm{Ma}$ and $\mathbf{b}$ from 0.8 to 1.5 Ma. Code numbers of marker dark layers (in Additional file 3: Table S1), marker tephras, and paleomagnetic event boundaries (in Table 1) are also shown. (TIF $6.55 \mathrm{mb}$ )

Additional file 2: Figure S2. a-d Correlation of GRA and NGR profiles at Site U1424 with LR04 benthic $\delta 180$ record of Lisiecki and Raymo (2005) during the last 3 My to construct LR04-tuned age model. Correlation points are numbered and listed in Table 2. Also shown at the bottom is $L^{*}$ profile with marker dark layer numbers during the last $1.5 \mathrm{Ma}$, whose ages and depths are listed in Additional file 3: Table S1. (TIF $8.26 \mathrm{mb}$ )

Additional file 3: Table S1. Code numbers and ages of marker dark layers and their composite depths (CCSFD_patched) at Sites U1422, U1423, U1424, U1425, U1426, and U1430. (XLSX $21 \mathrm{~kb}$ )

Additional file 4: Table S2. A list of linear sedimentation rates (LSRs) between two adjacent marker dark layer horizons at each site during the last 1.4 Ma (corresponding to Subunit IA) based on the two age models. (XLSX $69 \mathrm{~kb}$ )

Additional file 5: Figure S3. Temporal changes in linear sedimentation rates (LSRs) at all the studied sites during the last $1.45 \mathrm{Ma}$ calculated based on ages of marker dark layers whose ages are estimated based on LR04-tuned age model of U1424 (blue) and tephras and paleomagnetic events (orange). (TIF $4.45 \mathrm{mb}$ )

\section{Abbreviations}

CCD: Calcium carbonate compensation depth; CCSF: Core composite depth below sea floor; DL: Dark Layer; DOC: Dansgaard-Oeschger Cycle; GRA: Gamma ray attenuation; IODP: Integrated Ocean Drilling Program; IW: Interstitial water; LSR: Linear sedimentation rate; MAR: Mass accumulation rate; MIS: Marine isotope stage; NGR: Natural gamma ray; ODP: Ocean Drilling Program; RGB: Red-green-blue; TL: Thinly laminated; TWC: Tsushima Warm Current; XRF: X-ray fluorescence

\section{Acknowledgements}

We thank the technicians and crews of IODP Expedition 346 for their dedicated efforts to help us in retrieving high-quality cores and shipboard data that were used in this study. This research used samples and/or data provided by the Integrated Ocean Drilling Program (IODP).

\section{Funding}

This work was supported by a grant from IODP Exp. 346 After Cruise Research Program, JAMSTEC, awarded to TR, IK, Irino T, Itaki T, ST, KY, SS, and KA and from JSPS KAKENHI grant number $16 \mathrm{H} 01765$ awarded to TR.

\section{Authors' contributions}

Exp. 346 scientists collected basic data for this study during IODP Expedition to the Japan Sea. TR, MRW, and ZCA directed AWT Jr., BMA, BBJ, CSC, GMHC, DGR, GSJ, GL, HACG, HAE, IK, Irino T, Itaki T, KA, KCW, KY, LGS, LKE, L, LCICD, PMS, PLC, SRK, SS, ST, TS, WS, XC, ZH, and ZM to collect data. TR, Irino T, and IK proposed the topic and conceived and designed the study. TR, Irino T, IK, TS, KA, LS, and SA conducted detailed inter-site correlation of dark layers, SS and XC conducted revision of magneto-stratigraphy, and Itaki T and KY conducted revision of biostratigraphy. TR, Irino T, Itaki T, KA, LS, and SA drew figures, and TR wrote a draft of the manuscript. All authors read and approved the final manuscript.

\section{Authors' information}

TR and MRW were co-chief scientists, ZCA is a staff scientist, and IK, Irino T, Itaki T, ST, KY, SS, KA, XC, AWT Jr., BMA, BBJ, CSC, GMHC, DGR, GSJ, GL, HACG, HAE, KCW, LGS, LKE, L, LCICD, PMS, PLC, SRK, TS, WS, ZH, and ZM were shipboard scientists of IODP Expedition 346. KA and SA are students of TR, and LS is a student of Irino T.

\section{Competing interests}

The authors declare that they have no competing interests.

\section{Publisher's Note}

Springer Nature remains neutral with regard to jurisdictional claims in published maps and institutional affiliations.

\section{Author details}

${ }^{1}$ Graduate School of Science, The University of Tokyo, Tokyo, Japan. ${ }^{2}$ Faculty of Environmental Earth Science, Hokkaido University, Sapporo, Japan. ${ }^{3}$ Research Institute of Geology and Geoinformation, Geological Survey of Japan, AIST, Tsukuba, Japan. ${ }^{4}$ National Oceanography Centre Southampton, Southampton, UK. ${ }^{5}$ Institute of Science and Engineering, Kanazawa University, Kanazawa, Japan. ${ }^{6}$ Department of Geology and Paleontology, National Museum of Nature and Science, Tsukuba, Japan. ${ }^{7}$ Department of Earth and Environment, Boston University, Boston, USA. ${ }^{8}$ International Ocean Descovery Program, Texas A\&M University, College Station, USA. ${ }^{9}$ Marine Sciences, Florida International University, Miami, USA. ${ }^{10}$ Laboratoire CEFREM, Université de Perpignan, Perpignan, France. ${ }^{11}$ Department of Earth and Atmospheric Sciences, University of Nebraska, Lincoln, USA. ${ }^{12}$ Earth, Environmental, and Planetary Sciences, Brown University, Providence, USA. ${ }^{13}$ Escola de Artes, Ciencias e Humanidades (EACH), Universidade de São Paulo, São Paulo, Brazil. ${ }^{14}$ Department of Earth, Environmental, and Planetary Science, Rice University, Houston, USA. ${ }^{15}$ School of Earth Sciences, University of Melbourne, Melbourne, Australia. ${ }^{16}$ Present Address: Department of Geology and Geophysics, Woods Hole Oceanographic Institution, Woods Hole, USA. ${ }^{17}$ School of Geography, Politics and Sociology, University of Newcastle Upon Tyne, Newcastle Upon Tyne, UK. ${ }^{18}$ Institute for Geosciences, Christian-Albrechts-Universitat zu Kiel (IFM), Kiel, Germany. ${ }^{19}$ Department of Earth, Atmospheric and Planetary Sciences, Massachusetts Institute of Technology, Cambridge, USA. ${ }^{20}$ Petroleum and Marine Research Division, Korea Institute of Geoscience and Mineral Resources, Daejeon, South Korea. ${ }^{21}$ Department of Ocean Science, Korea Maritime and Ocean University, Busan, South Korea. ${ }^{22}$ Géosciences Montpellier, Université Montpellier II, Montpellier, France. ${ }^{23}$ IPMA, Lisbon, Portugal. ${ }^{24}$ Department of Geosciences, FB5, University of Bremen, Bremen, Germany. ${ }^{25}$ Rosenstiel School of Marine and Atmospheric Science, University of Miami, Miami, USA. ${ }^{26}$ School of Earth, Ocean and Climate Sciences, Indian Institute of Technology Bhubaneshwar, Bhubaneshwar, India. ${ }^{27}$ Centre Bretagne, IFREMER, Plouzané cedex, France.

${ }^{28}$ Institute of Oceanology, Chinese Academy of Sciences, Beijing, China.

${ }^{29}$ Present Address: Research Center for Earth System Science, Yunnan 
University, Kunming, China. ${ }^{30}$ Present Address: Department of Earth Sciences, Utrecht University, Utrecht, Netherlands.

Received: 30 November 2016 Accepted: 21 November 2017

Published online: 26 March 2018

\section{References}

Dansgaard W, Johnsen SJ, Clausen HB, Dahljensen D, Gundestrup NS, Hammer CU, Hvidberg CS, Steffensen JP, Sveinbjornsdottir AE, Jouzel J, Bond G (1993) Evidence for general instability of past climate from a 250-kyr ice-core record. Nature 364(6434):218-220. https://doi.org/10. 1038/364218a0

Gallagher SJ, Kitamura A, Iryu Y, Itaki T, Koizumi I, Hoiles PW (2015) The Pliocene to recent history of the Kuroshio and Tsushima Currents: a multi-proxy approach. Prog Earth Planet Sci 2:17. https://doi.org/10.1186/ s40645-015-0045-6

Gamo T, Nakayama N, Takahata N, Sano Y, Zhang J, Yamazaki E, Taniyasu S, Yamashita N (2014) The Sea of Japan and its unique chemistry revealed by time-series observations over the last 30 years. Monogr Environ Earth Planets 2(1):1-22. https://doi.org/10.5047/meep.2014.00201.0001

Ikehara K (2003) Late Quaternary seasonal sea-ice history of the northeastern Japan Sea. J Oceanogr 59(5):585-593. https://doi.org/10.1023/B:JOCE. $0000009588.49944 .3 d$

Irino T, Tada R, Ikehara K, Sagawa T, Karasuda A, Kurokawa S, Seki A, Lu S (in press) Construction of perfectly continuous records of physical properties for dark-light sediment sequences collected from the Japan Sea during Integrated Ocean Drilling Program Expedition 346 and their potential utilities as paleoceanographic studies. Prog Earth Planet Sci. https://doi.org/10.1186/ s40645-018-0176-7

Kido Y, Minami I, Tada R, Fujine K, Irino T, Ikehara K, Chun J-H (2007) Orbital-scale stratigraphy and high-resolution analysis of biogenic components and deepwater oxygenation conditions in the Japan Sea during the last $640 \mathrm{kyr}$. Palaeogeogr Palaeoclimatol Palaeoecol 247(1-2):32-49. https://doi.org/10. 1016/j.palaeo.2006.11.020

Lisiecki LE, Raymo ME (2005) A Pliocene-Pleistocene stack of 57 globally distributed benthic $\delta^{18} \mathrm{O}$ records. Paleoceanography 20(1):PA1003. https://doi.org/10.1029/2004PA001071

Sagawa T, Nagahashi Y, Satoguchi Y, Holborn A, Itaki T, Gallagher SJ, SaavedraPellitero M, Ikehara K, Irino T, Tada R (in press) Integrated tephrostratigraphy and stable isotope stratigraphy in the Japan Sea and East China Sea using IODP Sites U1426, U1427 and U1429, Expedition 346 Asian Monsoon. Prog Earth Planet Sci. https://doi.org/10.1186/s40645-018-0168-7.

Satoguchi Y, Nagahashi Y (2012) Tephrostratigraphy of the Pliocene to Middle Pleistocene Series in Honshu and Kyushu Islands, Japan. Island Arc 21 (3):149-169

Seki A (2017) Reconstruction of marine organic matter content in the sediments and deep-water redox condition variability of the Japan Sea during the Quaternary using high-resolution XRF core scanner. Doctoral Thesis, Graduate School of Science, the University of Tokyo, p 198

Tada R (1994) Paleoceanographic evolution of the Japan Sea. Palaeogeogr Palaeoclimatol Palaeoecol 108(3-4):487-508. https://doi.org/10.1016/00310182(94)90248-8

Tada R (2005) Onset and evolution of millennial-scale variability in the Asian Monsoon and its impact on paleoceanography of the Japan Sea. Millennial-Scale Variability in the Asian Monsoon, American Geological Union, U.S.A, pp 1-16

Tada R (2012) The Japan Sea sediments and variability of East Asian Monsoon: toward the IODP drilling of the Japan Sea and East China Sea. Quat Res (Tokyo) 51(3):151-164

Tada R, lijima A (1983) Petrology and diagenetic changes of Neogene siliceous rocks in northern Japan. J Sediment Petrol 53(3):911-930

Tada R, Irino T, Koizumi I (1999) Land-ocean linkages over orbital and millennial timescales recorded in late Quaternary sediments of the Japan Sea. Paleoceanography 14(2):236-247

Tada R, Koizumi I, Cramp A, Rahman A (1992) Correlation of dark and light layers, and the origin of their cyclicity in the Quaternary sediments from the Japan Sea. In Pisciotto, K. A., Ingle, J. C, Jr., von Breymann, M. T., Barron, J., et al. Proc ODP, Sci results, 127/128, Pt. 1: 577-601 College Station(Ocean Drilling Program)
Tada R, Murray RW, Alvarez Zarikian CA, the Expedition 346 Scientists (2015) Proceedings of Integrated Ocean Drilling Program. IODP, vol 346. Integrated Ocean Drilling Program, College Station. https://doi.org/10. 2204/iodp.proc.346.101

Talley LD, Min DH, Lobanov VB, Luchin VA, Ponomarev VI, Salyuk AN, Shcherbina AY, Tishchenko PY, Zhabin I (2006) Japan/East Sea water masses and their relation to the sea's circulation. Oceanography 19(3):32-49

Tamaki K, Pisciotto KA, Allan J, et al. (1990) Proceedings of Ocean Drilling Project. Initial Reports, 127, College Station, TX (Ocean Drilling Program). https://doi.org/10.2973/odp.proc.ir.127.1990

Watanabe S, Tada R, Ikehara K, Fujine K, Kido Y (2007) Sediment fabrics, oxygenation history, and circulation modes of Japan Sea during the Late Quaternary. Palaeogeogr Palaeoclimatol Palaeoecol 247(1-2):50-64. https://doi.org/10.1016/j.palaeo.2006.11.021

\section{Submit your manuscript to a SpringerOpen ${ }^{\circ}$ journal and benefit from:}

- Convenient online submission

- Rigorous peer review

- Open access: articles freely available online

- High visibility within the field

- Retaining the copyright to your article

Submit your next manuscript at springeropen.com 